\title{
A Review of Air Quality and Concentrations of Air Pollutants in Nigeria
}

\author{
*11ABAJE, IB; ${ }^{1}$ BELLO, Y $;{ }^{2}$ AHMAD, SA \\ ${ }^{I}$ Department of Geography and Regional Planning, Federal University Dutsin-Ma, \\ P.M.B. 5001 Dutsin-Ma, Katsina State, Nigeria. \\ ${ }^{2}$ CPES, Federal University of Technology, Minna, Nigeria. \\ *Corresponding Author Email: abajebest@gmail.com; Tel: +234 (0)8036642086, +234 (0)8027942167
}

\begin{abstract}
This study generally classifies air pollutants on the basis of: primary or secondary, natural or anthropogenic, chemical composition, physical state, and the space scales of their effects. Air pollutants that affect air quality in Nigeria were discussed based on natural and anthropogenic sources. The natural sources include: sand dust, sea spray, volcanic activities, smoke and carbon monoxide from wildfires among others, while the anthropogenic sources include: vehicular emissions, mining activities, industries such as cement companies and quarry factories, agricultural practices and solid waste dumps among others. Some of the atmospheric pollutants that posed greatest threat to human health were equally examined. They include: Sulphur dioxide $\left(\mathrm{SO}_{2}\right)$ which can react with water vapor $\left(\mathrm{H}_{2} \mathrm{O}\right)$ in the atmosphere to form sulphuric acid $\left(\mathrm{H}_{2} \mathrm{SO}_{4}\right)$ and thus acid rain; particulate matter (PM) with less than $10 \mu \mathrm{m}$, particularly fine particles $\left(\mathrm{PM}_{2.5}\right)$ and particles in the fine fraction that are smaller than $0.1 \mu \mathrm{m}$ (ultrafine particles), can carry toxic chemicals which are linked to cancer; carbon monoxide (CO), even in very small concentrations, can prevent oxygen from being delivered through the body major organs; ozone which is a highly reactive gas causes oxidation of a number of macromolecules within a biological system and produces free radicals that can damage DNA molecules and cause carcinogenesis. Based on the aforementioned, this study recommends that priority should be given to the establishment of air monitoring stations in all urban centers of the country in order to provide accurate and continuous information on air quality.
\end{abstract}

\section{DOI: https://dx.doi.org/10.4314/jasem.v24i2.25}

Copyright: Copyright $(\underset{C}{ } 2020$ Abaje et al. This is an open access article distributed under the Creative Commons Attribution License (CCL), which permits unrestricted use, distribution, and reproduction in any medium, provided the original work is properly cited.

Dates: Received: 16 November 2019; Revised: 11 January 2020; Accepted: 22 February 2020

Keywords: anthropogenic pollutants, atmosphere, particulate matter, pollution

The earth is enveloped by a thick blanket of gases. This gaseous cover of the earth is known as the atmosphere, and it is held to the earth by the force of gravity (Chandna, 2014). It consists of $78 \%$ nitrogen and $21 \%$ oxygen, with the remainder consisting of argon, carbon dioxide $\left(\mathrm{CO}_{2}\right)$, ozone $\left(\mathrm{O}_{3}\right)$ and water vapour. Other gases such as neon, krpton, helium, methane, hydrogen, etc. occur in very small proportions. The atmosphere also contains suspended liquid and solid particles, collectively called aerosols, extending several thousands of kilometers above the earth's surface (Chandna, 2014). Studies have revealed that these atmospheric particles can lead to the reduction of biodiversity and the quality of goods and services offered by ecosystems (Amos et al, 2015). Air pollution is one of the environmental problems confronting growing cities and is currently the challenge faced by many developed and developing countries (Komolafe et al, 2014). Romans complained over 2000 years ago about the foul air of their cities. Filling Roman air was the stench of open sewers, smoke from fires, and fumes from ceramicmaking kilns and smelters that converted ores into metals. In human experience, cities are always the place where the environment's natural ability to process and recycle waste is most taxed (Christopherson, 2006). Air pollution is the introduction of chemicals, particulate matter, or biological materials that cause harm or discomfort to humans or other living organisms, or cause damage to the natural environment or built environment, into the atmosphere (Tawari and Abowei, 2012). It is the second major attribute of urban climate after the heat island phenomenon (Ayoade, 2012). It can occur as a result of natural conditions. Various anthropogenic activities have either increased the content level of some of the natural pollutants or have added new pollutants to the air. Consequently, the air quality has deteriorated significantly and the atmosphere in general stands polluted considerably (Chandna, 2014). The effects on human lives are enormous as it causes disease and can result in chronic illness. Apart from the health effects, air pollution contributes to our changing climatic conditions, which are potential sources of threats to local and international communities (Komolafe et al, 2014). For example, increased in technological development and subsequent high level industrialization have resulted to increase in greenhouse gases (GHGs) and hence 
increase in global temperatures (Abaje et al, 2016; Abaje and Oladipo, 2019).

Since the discovery of oil in the 1950s, Nigeria has been suffering the negative environmental consequences of oil development. The growth of the country's oil industry, combined with a population explosion and a lack of environmental regulation, led to substantial damage to Nigeria's environment especially the Niger Delta region which is the center of the country's oil industry (Tawari and Abowei, 2012). The country also faces environmental challenges from air pollution and desertification, with the encroachment of the Sahara desert in the north and severe air pollution in overcrowded cities such as Kano, Kaduna, Abuja, and Lagos, among others.

From the aforementioned, it is clear that both natural and anthropogenic sources of air pollution determine the conditions found in the atmosphere in Nigeria, and since the atmosphere affects the life of everyone, therefore, the main objective is to increase awareness and understanding of the major air pollutants, their sources, health effects, and the controlling measures of air pollution in Nigeria.

Sources of Data: This is a review paper, therefore, data used for this study were obtained from secondary sources. Relevant publications like books, research journals, magazines, internet materials, among others, on air pollution with particular reference to Nigeria were consulted and relevant information were extracted.

Classification of Air Pollutants: Air pollutants are harmful solid, liquid or gaseous substances that are present in the atmosphere in such concentrations that tend to be injurious to living organisms and the environment. They pollute the air and only come in contact with the biosphere when they are unable to go high up in the atmosphere (Asthana and Asthana, 2006; Ukemenam, 2014). They can be classified into different forms based on certain criteria namely:

Primary or Secondary: Primary pollutants are those that cause direct harm or that can react to form harmful substances in the atmosphere. They are substances directly emitted from a process such as ash from a volcanic eruption, the carbon monoxide (CO) gas from a motor vehicle exhaust or sulphur dioxide released from factories. Secondary pollutants are not emitted directly, but rather, they are created from the reactions between primary pollutants and the components of the atmosphere. A good example of a secondary pollutant is ground level ozone. It is important to note that some pollutants may be both primary and secondary, that is, they are both emitted directly and formed from other primary pollutants (Ukemenam, 2014; Ede and Edokpa, 2015).

Natural or Anthropogenic: Natural pollutants include dusts or particulate matters, sea spray, decayed vegetation, smoke and $\mathrm{CO}$ from wildfires, while the anthropogenic pollutants include all chemicals that are produced by Man that caused significant alteration in the normal gaseous composition of the atmosphere (Tawari and Abowei, 2012; Ukemenam, 2014, Asubiojo, 2016).

Chemical Composition: Their names have been given according to the prominent chemical compounds they contain: Sulphur-containing compounds; nitrogen containing compounds; carbon-containing compounds; halogen-containing compounds; toxic substances; and radioactive compounds (Ukemenam, 2014).

Physical State: Pollutants are classified as solid, liquid, or gaseous substances.

The Space Scales of their Effects: Pollutants are classified as local (or indoor), regional, or global (Ukemenam, 2014).

Major Pollutants of the Atmosphere: Some of the major pollutants of the atmosphere that posed the greatest threat to human health include:

Particulate Matter: Particulate matter (PM) is a complex mixture of solids and liquids, including carbon, complex organic chemicals, sulphates, nitrates, mineral dust, and water suspended in the air. PM can be generated by industry, transport and agriculture, and due to their light weight, can also be carried on air currents from one country to another. The size of the particle is very important in determining their behavior in the air, the distance and the height up to which they will be carried by air currents and the effect they will have on the organism inhaling them or on plants which have to exchange gases through their stomata (Asthana and Asthana, 2006). Total suspended Particulates (TSP) refers to particles with a diameter greater than 10 microns $(\mu \mathrm{m})$, such as dust, soot, dirt or smoke that are large or dark enough to be seen with the naked eye. But the most damaging particles are the smaller particles, known as $\mathrm{PM}_{10}$ and $\mathrm{PM}_{2.5}$. $\mathrm{PM}_{10}$ refers to particles with a diameter less than $10 \mu \mathrm{m} . \mathrm{PM}_{2.5}$ refers to particles with a diameter less than $2.5 \mu \mathrm{m}$, and these are known as fine particles. The smallest fine particles, less than 0.1 $\mu \mathrm{m}$ in diameter, are called ultrafine particles (Abulude, 2016). 
Sulphur Oxides: The most common sulphur pollutant is sulphur dioxide $\left(\mathrm{SO}_{2}\right)$. It is a colourless gas, with a pungent, suffocating smell. It occurs in coal and fossil fuel as natural contaminant. When burning of these fossil fuels take place, $\mathrm{SO}_{2}$ get emitted. It also has 1$3 \%$ of Sulphur trioxide $\left(\mathrm{SO}_{3}\right)$ in gaseous form. Consequently, $\mathrm{SO}_{2}$ get further oxidized into $\mathrm{SO}_{3} \cdot \mathrm{SO}_{2}$ also reacts with water vapors present in the atmosphere and gets dissolved into water droplets which is then converted into sulphuric acid $\left(\mathrm{H}_{2} \mathrm{SO}_{4}\right)$ and thus acid rain. $\mathrm{SO}_{2}$ itself can also directly form a weak acid $\left(\mathrm{H}_{2} \mathrm{SO}_{3}\right)$. In addition to $\mathrm{H}_{2} \mathrm{SO}_{4}$ and $\mathrm{H}_{2} \mathrm{SO}_{3}$, sulphate iron also gets generated in a variety of solid and liquid particulates (Chandna, 2014). These acids and sulphates are the most dangerous forms of sulphur as far as their impact on health is concerned.

Carbon Oxides: Combustion of organic matter and fossil fuels in the presence of oxygen results in the formation of $\mathrm{CO}_{2}$ while $\mathrm{CO}$ is formed due to incomplete combustion of these materials under oxygen deficient conditions. $\mathrm{CO}$ is a colorless, ordorless, non-irritating but very poisonous gas (Ukemenam, 2014). It is the most important atmospheric pollutant as it accounts for about $52 \%$ of the total air pollution. The commonest source of $\mathrm{CO}$ pollution in cities are automobile exhausts. Other sources of $\mathrm{CO}$ are various metallurgical operations, domestic combustion of coal, dried organic matter, fuel gases, etc. This pollutant is dangerous to human health because even in very small concentrations, it can prevent oxygen from being delivered through the body major organs. At higher levels, it can leads to death. $\mathrm{CO}_{2}$ is a colourless, odourless, non-toxic GHG which is produced in large amounts when organisms respire. Incineration of limestone for the production of cement and lime, various metallurgical operations and a number of industrial practices also produce a large amount of this gas (Asthana and Asthana, 2006).

Nitrogen Oxides: The three oxides of nitrogen which are important pollutant of the atmosphere are: nitrous oxide $\left(\mathrm{N}_{2} \mathrm{O}\right)$, nitric oxide $(\mathrm{NO})$ and nitrogen dioxide $\left(\mathrm{NO}_{2}\right)$. Most of these oxides are introduced in considerable amount by burning fossil fuels, organic matter as well as by microbial action on nitrogenous organic matter and on chemical fertilizers applied in agricultural fields. It has been estimated that about 70$80 \%$ of the total input of $\mathrm{N}_{2} \mathrm{O}$ comes from natural sources and the breakdown of nitrogenous fertilizers. $\mathrm{N}_{2} \mathrm{O}$ is not very harmful to plants and animals but it gives rise to $\mathrm{NO}$ and $\mathrm{NO}_{2}$ which are much more injurious. Once $\mathrm{NO}_{2}$ is generated, it reacts readily with water vapor to form nitric acid $\left(\mathrm{HNO}_{3}\right)$ (Chandna, 2014). Nitric oxide is responsible for the depletion of the ozone layer while $\mathrm{NO}_{2}$ is an important constituent of the photochemical smog or oxidizing type of air pollution and partially responsible for causing acid rain.

Ozone: Ozone $\left(\mathrm{O}_{3}\right)$ is produced by the breaking up of molecular oxygen $\left(\mathrm{O}_{2}\right)$ at $\mathrm{UV}$ wavelengths below $242 \mathrm{~nm}$ (photolysis) to form oxygen atoms (O), followed by the reaction of oxygen atoms with $\mathrm{O}_{2}$ to form ozone. The upper layers of the atmosphere are irradiated by UV radiations from the sun that causes the breakup of oxygen molecules at altitude above 30 $\mathrm{km}$. These separate atoms $(\mathrm{O}+\mathrm{O})$ may then combine individually with other oxygen molecules to create ozone (Abaje et al, 2017). Ozone is highly reactive gas which causes oxidation of a number of macromolecules within a biological system and produces free radicals which have been implicated in a number of ozone induced pulmonary or extrapulmonary damages. These free radicals can damage DNA molecules and cause carcinogenesis (Abaje et al, 2017).

Radioactive Pollutants: These are produced by nuclear explosions, war explosives and natural processes such as the radioactive decay of radon (Ukemenam, 2014).

Hydrocarbons: Biological decomposition of organic matter, natural gas, volatile emissions, incomplete combustion of fossil fuels and biomass, automobile exhausts, etc. are some of the sources of hydrocarbons in the atmosphere. The harmful effects that are caused by these hydrocarbons vary from compound to compound. Most of them are known to have carcinogenic properties which are believed to cause cancer (Chandna, 2014). The most important hydrocarbons are: methane $\left(\mathrm{CH}_{4}\right)$, carbon dioxide $\left(\mathrm{CO}_{2}\right)$, halocarbons (a group of gases containing fluorine, chlorine and bromine) such as chlorofluorocarbons (CFCs), among others are GHGs. CFCs are synthetic molecules of chlorine, fluorine and carbon. These GHGs are capable of blocking infra-red and heat waves from escaping the earth's surface (Christopherson, 2006). Other hydrocarbons include aromatic hydrocarbons, poly-nuclear aromatic compounds, aldehydes, Peroxyalkyl nitrates which may form compounds like Peroxyacetyl nitrate (PAN) and Peroxybenzonyl nitrate (PBN) that cause irritation of eyes.

Sources of Air Pollution That Affect Air Quality in Nigeria: There are two major sources of air pollution that affect air quality in Nigeria, natural and anthropogenic sources; although it is the anthropogenic sources that produce most of the pollutants especially in the urban areas. 
Natural Sources of Air Pollution: Major natural sources of air pollution in Nigeria are as follows:

Sand Dust: Atmospheric dust arises from storms in arid and semi-arid regions of the Northern part of the country, and such dust travels over long distances. A good example is harmattan dust which is felt in the December/January months of the year all over Nigeria and whose origin has been traced to the Faya Largeau area of the Chad basin (Tawari and Abowei, 2012; Asubiojo, 2016). The severity and length of the harmattan dust is greatest near the Sahara desert (arid and semi-arid regions Northern Nigeria) and decreases southwards such that near the ocean only a few days carry harmattan dust. For example, as much as 1033 $\mathrm{g} / \mathrm{m}^{3}$ of dust was recorded in Kano and $329 \mathrm{~g} / \mathrm{m}^{3}$ in IleIfe during the harmattan period of 1993 (Asubiojo, 2016).

Sea spray: Sea spry leaves particles of Sodium Chloride $(\mathrm{NaCl})$ in the air after evaporation of the water. This is observed in the coastal air shed of Lagos (Asubiojo, 2016).

Methane can be introduced into the atmosphere as a result of bacterial metabolism of decaying plant materials in wetlands as well as of cellulose in the guts of termites and ruminant animals such as cows, sheep and goats (Asubiojo, 2016). During the normal digestion process, these animals create large amounts of methane. Enteric fermentation occurs because of microorganisms in the stomach of these animals. This creates methane as a by-product that is either exhaled by the animal or released via flatus.

Radon gas from radioactive decay within the Earth's crust. Radon is a colorless, odorless, natural radioactive noble gas that is formed from the radioactive decay of radium. It is considered to be a health hazard. Radon gas from natural sources can accumulate in buildings, especially in confined areas such as the basement, and it is the second most frequent cause of lung cancer, after cigarette smoking (Tawari and Abowei, 2012).

Other natural sources of air pollution include: smoke and $\mathrm{CO}$ from wildfires, and volcanic activities (e.g. Jos and Biu Plateaux) which produce sulfur, chlorine and ash particulates.

Anthropogenic Sources of Air Pollution: Some of the major anthropogenic sources of air pollution include:

Vehicular Emissions within Urban Centers: Increased pollution from mobile sources is on the increase with per capita increase in vehicle ownership. The consequence of this is the congestion of most Nigeria city roads and a corresponding increase in the burden of air pollutants and their associated effects (Ukemenam, 2014). A significant percentage of air pollutant particularly $\mathrm{CO}_{2}$ and $\mathrm{CO}$ are emitted from traffic congestion within the major cities in Nigeria such as: Abuja, Lagos, Calabar, Kano, Kaduna, Onitsha, Enugu, etc. In Nigeria, most of the vehicles imported are either old or fairly used which have incomplete combustion and therefore, emit a lot of CO into the atmosphere. Atmospheric pollutants from vehicles according to Asubiojo (2016) are of two types: exhaust and non-exhaust emissions. Emissions from the exhaust are products of fuel combustion such as $\mathrm{NO}, \mathrm{SO}, \mathrm{CO}, \mathrm{CO}_{2}$, VOCs and some quantities of particulate matter containing toxic heavy metals $(\mathrm{V}$, $\mathrm{Cd}$, As and also $\mathrm{Pb}$ in cases of leaded gasoline) while the non-exhaust emissions include particles from brake wear, tyre wear, road surface abrasion and resuspension in the wake of passing traffic.

Gasoline Generator: Similar to vehicular emissions is the use of gasoline generator. The inability of the Power Holding Company of Nigeria (PHCN) to supply electricity to households, businesses and industries has compels people to use fossil fuel electric power generators. These generators release $\mathrm{CO}$ into the atmosphere causing air pollution (Dankani, 2012).

Mining: Mining of solid minerals from the earth's surface is another means in which air gets polluted through land site clearing, drilling, blasting, hauling, collection, and transportation. This involves the use of machines that operates on fuel which emits a lot of harmful gases such as $\mathrm{SO}, \mathrm{NO}, \mathrm{CO}$ and particulate matter into the atmosphere. Coal mining produces methane, a potent GHG, with a global warming potential 21 times greater than that of $\mathrm{CO}_{2}$ on a $100-$ year time line (Asubiojo, 2016). Opencast mining which involved clearing of the vegetation in preparing grounds for mining will result in dust flying in the atmosphere. Deforestation increases the $\mathrm{CO}_{2}$ content of the atmosphere thereby aiding global warming and oxygen is drastically reduced (Ikwuagwu, 2017). Mining is actively taking place in Amansiodo, Inyi and Ezinmo coal mine in Enugu State, Ogboyoga and Okaba coal mine in Kogi State, Okpara mine in Anambra State, Owupka mine in Benue State, Maiganga coal mine in Gombe State, and Tin and Columbine mine in Jos. All these locations generate air pollutants as a result of the mining activities.

Fuel Wood: A large percentage of the people in rural and urban centers uses fuelwood for domestic cooking and heating. Also, small scale industries such as bakeries and businesses such as restaurants use 
fuelwood during their production processes. Many people are using fuelwood due to the absence of cheap and readily available sources of fuel for cooking in Nigeria (Ladan, 2013). The burning of the wood has become a major source of indoor air pollution in the rural and urban centers. National Bureau of Statistics [NBS] (2007) reported that $95.9 \%$ of the households in North-East (NE) Nigeria consume fuelwood while only $54.9 \%$ in South-West (SW) Nigeria consume fuelwood. In view of this, the Northeastern part of the country contributes more to air pollution than the Southwestern part. Food and Agricultural Organization [FAO] (2005) also reported that a total removal of fuelwood from forests in the year 2005 was $72,710,935 \mathrm{~m}^{3}$. The removal of fuelwood from these sources will create a loss in the carbon sink in the environment which contributes to the cause of global warming.

Industries: The greatest contributors of particulate dust are cement and metal-smelting industries. Cement companies in Nigeria include: Dangote Cement Plc located at Obajana and Gboko in Kogi and Benue States respectively, Cement Company of Northern Nigeria in Sokoto, Ashaka Cement Plc in Gombe State, Edo Cement Company Plc in Edo Okpella, among others. As much as 56,100 g/m of particulate dust have been measured in a cement factory vicinity and $12,320 \mathrm{~g} / \mathrm{m}$ in a metal smelting factory premises (Asubiojo, 2016). Quarry factories contribute more to the emission of particulate matter, the dust generated from stone crushing activities contains a significant amount of fine inhaled dust which affects human health. Industrial air pollutants such as $\mathrm{SO}_{2}$, nitrogen oxides and carbon monoxide are generated from most industries located in Kano and Kaduna in the North; Lagos, Ogun and Ibadan in the South West; and Onisha and Aba in the South East. One of the most industrialized part of the country is the Niger Delta Region. The region boasts of oil and non-oil related industries including refinery, petrochemical, liquefied natural gas, chemical fertilizer, aluminium smelter, flour, wood, battery textile industries, etc., which emit various kinds of air pollutants (Tawari and Abowei, 2012; Ukemenam, 2014; Asubiojo, 2016). All these pollutants affect air quality in the country.

Agricultural Practices: Agricultural activities contribute to atmospheric pollution through various practices such as bush burning and the use chemicals (insecticides, pesticides and fungicides). Burning of bush is done prior to land cultivation as one of the initial steps of land preparation. The process leads to the release of various types of gaseous pollutants and particulate matter. Very often the gas stream is inundated with volatile organics and oxides of carbon, sulphur and nitrogen depending on the fuel composition and intensity of the flame. Particulate matter usually within the $10 \mu \mathrm{m}$ size range is also produced in the course of the combustion process (Tawari and Abowei, 2012; Ukemenam, 2014). The clearing of natural vegetation to create land for agricultural activities takes away the dust absorbers and give room for some of the dust to be floating around in the air; also cutting down of some trees and shrubs to feed animals equally reduces the carbon sink and increase the ambient temperature. A range of pollutant gases related to nitrogen compounds $\left(\mathrm{NO}_{2}\right.$, $\mathrm{NO}, \mathrm{NH}_{3}, \mathrm{~N}_{2} \mathrm{O}$ ) are also emitted to the atmosphere from agricultural activities such as the use of fertilizer and livestock waste. Also in common use are pesticides such as Aldrin, Dieldrin, and the banned dichloro-diphenyl-trichloro-ethane (DDT) which are all toxic volatile liquids that are non- biodegradable, and the use of copper fungicides in cocoa plantations in southern Nigeria (Asubiojo, 2016).

Solid Waste Dumps: The problem of solid waste disposal is a major environmental issue in Nigeria, particularly in the urban centers. The solid waste is usually from multiple sources including domestic, municipal, agricultural and industrial sources. A common practice of solving this problem is disposal at designated sites. However, this is an indirect source of atmospheric pollution by way of biodegradation of organic waste producing methane and other gaseous toxins (Asubiojo, 2016). Closely related to this is burning of solid waste which generates VOCs, $\mathrm{CO}_{2}$, $\mathrm{CO}, \mathrm{SO}, \mathrm{NO}$, and Total Hydrocarbons (THCs) into the atmosphere, as well as various classes of toxic and hazardous compounds via Polycyclic Aromatic Hydrocarbons (PAHs), dioxins, Polychloro Biphenyls (PCBs) and heavy metals such as lead, nickel and mercury (Tawari and Abowei, 2012; Ukemenam, 2014).

Effects of Air Pollution on Human Health: Several studies have found an association between air pollution and human health. A study in 2016 on the Global Burden of Disease estimates that $7.5 \%$ of deaths globally were attributable to ambient air pollution. In the same year, $27.5 \%$ of deaths due to Lower Respiratory Tract Infections and 26.8\% of deaths due to Chronic Obstructive Pulmonary Diseases were also linked to air pollution ( $\mathrm{Li}$ and Mallat, 2018). Particulate matter, especially the smaller particles $\left(\mathrm{PM}_{10}\right.$ and $\left.\mathrm{PM}_{2.5}\right)$, have the most harmful effects on human health than any other pollutant (Komolafe et al, 2014). The largest sources of PM according to Center for Ecogenetics and Environmental Health, CEEH (2012) are vehicle emissions and wood smoke. WHO estimated that 
$\mathrm{PM}_{2.5}$ contributes to 800,000 premature deaths per year. Exposure to $\mathrm{PM}_{2.5}$ for just a few hours or weeks, according to the center, can cause cardiovascular effects including atherosclerosis, heart failure, heart attack, stroke, arrhythmia, thrombosis, and death. Brief exposure is more dangerous for people with preexisting cardiac artery disease, people with diabetes or obesity, and the elderly. Other health effects are lung diseases including asthma, chronic obstructive pulmonary disease, chronic bronchitis, reduced lung function, and lung cancer. The size of PM will determine where it will end up once you breathe it in. Larger particles may be trapped in your nose, while $\mathrm{PM}_{10}$ can reach your airways. Fine particles $\left(\mathrm{PM}_{2.5}\right)$ may reach the breathing sacs deep in your lungs, and ultrafine particles (less than $0.1 \mu \mathrm{m}$ in diameter) may even cross into your blood stream. Cases of respiratory diseases and even death have been reported in some Nigerian cities (Lagos, Port Harcourt, and Kano) (Komolafe et al., 2014). $\mathrm{SO}_{2}$ is absorbed mainly in the upper airway causing chronic bronchitis or asthma. $\mathrm{O}_{3}$, $\mathrm{NO}_{2}$ and other insoluble gaseous substances may reach deep in the lungs, causing asthma or chronic bronchitis or possibly pulmonary emphysema (Ukemenam, 2014). Studies, according to CEEH (2012), show that incidence of lung cancer increases with long-term exposure to vehicular emissions due to traffic congestion and the closer a residence is to a major road. Children who live or attend school close to traffic also have an increased risk of asthma.

Dumpsites are known for their smelly and unsightly conditions. These conditions are worse in the Northern parts of Nigeria during summer as a result of high temperatures. This speeds up the rate of bacterial action on biodegradable organic material and, therefore, emit obnoxious odours and smoke, and thus, a source of airborne chemical contamination that cause illness to people. A wide range of health problems, including irritation of the skin, nose, and eyes, gastrointestinal problems, psychological disorders, and allergies, among others have been found to be associated with people living in, around, or closer to these open dumpsites (Abul, 2010).

Air Pollution Control: Air pollution can be controlled in Nigeria through the following:

i. Reduction of emissions at source through the use of clean energy or more efficient combustion processes in industries, homes, and transportation systems. For examples, the use of electricity, cooking gas, wind or solar energy instead of fossil fuels will reduce the emission of pollutants, and also the use of scrubbers in industries in order to remove some of the harmful substances that would otherwise pollute the air. ii. Enforcement of air pollution legislation across the country (Ayoade, 2012) in order to regulate air quality through: 1) setting standards for pollution levels and or limiting emissions for various types of pollutants; 2) screening new substances in order to determine their safety before they are used; 3) requiring a comprehensive evaluation of the environmental impact of an activity or project before it is undertaken; and, 4) taxing of industries based on the amount of pollutants they produced, that is, Polluter Pay Principle.

iii. In addition to regular servicing of vehicles and those that emit too much smoke to be taken off the roads, catalytic converters that causes chemical reaction that changes exhaust emissions to less harmful substances should be used in the exhaust of automobiles.

iv. In order to reduce air pollution through waste decomposition in urban centers, there should be regular waste collection and proper disposal, and control measures be placed on burning of refuse within urban centers.

v. Planting of plant with high air pollution tolerance within the vulnerable areas should be encouraged. Also, vegetation should be planted around mining and quarrying sites to prevent dust from escaping to the environment.

vi. Government should establish air monitoring stations in all urban centers of the country in order to provide accurate and continuous information on air quality.

vii. Education and enlightenment programs are critical in making the general public aware of the effects of air pollution. This is because the ability to effectively respond to air pollution challenges is determined by the quality of information available to the people and how easily they can access it (Abaje and Oladipo, 2019). Information containing the dangers and health hazards of air pollution and how to control it can be delivered through radio and television programs, issuance of newsletter, booklets, reports, and videos among others.

Conclusions: Air pollution is one of the most widespread forms of pollution in Nigeria. This study has classified air pollutants into various forms, and some of the major pollutants that posed the greatest threat to human health were reviewed. The study also examined the natural and anthropogenic sources of air pollution that affect air quality in Nigeria, and the effects on human health. Based on the reviewed, solutions to air pollution require regional and national strategies, as well as government coordination. This is because the pollution sources often are distance from the observed impact-moving across both local and national political boundaries and even crossing 
oceans. Therefore, priority should be given to the establishment of air monitoring stations in all urban centers of the country in order to provide accurate and continuous information on air quality.

\section{REFERENCES}

Abaje, IB; Oladipo, EO (2019). Recent Changes in the Temperature and Rainfall Conditions Over Kaduna State, Nigeria. Ghana Journal of Geography, 11 (2), 127-157.

Abaje, IB; Abdullahi, N; Jeje, OG (2016). Climate Change and Infectious Diseases in Funtua Local Government Area of Katsina State, Nigeria. International Journal of Science and Technology (STECH), 5 (1), 47-58.

Abaje, IB; Olatunde, AF; Ati, OF (2017). Human health effects of ozone layer depletion and interactions with climate change: A review. Journal of Geography and Development, 7 (1), 822-835.

Abul, S (2010). Environmental and Health Impact of Solid Waste Disposal at Mangwaneni Dumpsite in Manzini: Swaziland. Journal of Sustainable Development in Africa, 12 (7), 64 -78.

Abulude, FO (2016). Particulate Matter: An approach to air pollution. Preprints, pp 14, doi:10.20944/preprints201607.0057.v1.

Amos, BB; Musa, I; Abashiya, M; Abaje, IB (2015). Impacts of Cement Dust Emissions on Soils within $10 \mathrm{~km}$ Radius in Ashaka Area, Gombe State, Nigeria. Environment and Pollution, 4 (1), 29-36.

Asthana, DK; Asthana, M (2006). Environment: Problems and Solutions. Second Revised Edition. New Delhi: S. Chand \& Company Ltd.

Asubiojo, OI (2016). Pollution Sources in the Nigerian environment and their health implications. Ife Journal of Science, 18 (4), 974-980

Ayoade, JO (2012). Introduction to Building and Urban Climatology, $1^{\text {st }}$ Edition. Ibadan: Agbo Areo Publishers.

Center for Ecogenetics and Environmental Health (2012). Health Effects of Air Pollution. University of Washington. Retrieved from https://depts.washington.edu/ceeh/downloads/FF_A irPollution.pdf
Chandna, RC (2014). Environmental Geography, $4^{\text {th }}$ Enlarged Edition. New Delhi: Kalyani Publishers

Christopherson, RW (2006). Geosystems: An Introduction to Physical Geography, $6^{\text {th }}$ Edition. New Jersey: Pearson Prentice Hall.

Dankani, IM (2012). Electricity Generator Usage in Kano Walled City: The Climate Change Implication. In Iliya, M.A., and Dankani, I.M. (Eds), Climate Change and Sustainable Development in Nigeria, (pp. 229 - 249). Ibadan: Crown F. Publishers.

Ede, PN; Edokpa, DO (2015). Regional air quality of the Nigeria's Niger Delta. Open Journal of Air Pollution, 4, 7-15.

Food and Agricultural Organization, FAO (2005). Global Forest Resources Assessment 2005. FAO Forestry, Paper 147: Progress towards sustainable forest management. Retrieved from ftp://ftp.fao.org/docrep/fao/008/A0400E/A0400E00.pdf.

Ikwuagwu, CS (2017). Environmental and health implications of coal mining at Maiganga, Gombe State, Nigeria. Journal of Environment Pollution and Human Health, 5 (1), 5-14

Komolafe, AA; Adegboyega, SA; Anifowose, AYB; Akinluyi, FO Awoniran, DR (2014). Air pollution and climate change in Lagos, Nigeria: Needs for proactive approaches to risk management and adaptation. American Journal of Environmental Sciences, 10 (4), 412-423.

Ladan, SI (2013). Examining air pollution and control measures in urban centers of Nigeria. International Journal of Environmental Engineering and Management, 4(6), 621-628

Li, M; Mallat, L (2018). Health impacts of air pollution. SCOR Paper NO. 42. Retrieved from https://www.scor.com/sites/default/files/sp42air pollution.pdf

National Bureau of Statistics (2007). Annual abstracts of statistics. National Bureau of statistics, Abuja, Nigeria.

Tawari, CC; Abowei, JFN (2012). Air pollution in the Niger Delta Area of Nigeria. International Journal of Fisheries and Aquatic Sciences, 1(2), 94-117.

Ukemenam, OS (2014). Causes and consequences of air pollution in Nigeria. South American Journal of Public Health, 2 (2), 293-307. 